\title{
Evaluation of Special Pedagogical Support in Early Childhood Education Institutions: the Attitude of Parents and Teachers
}

\author{
Asta Rauduvaite $^{1}$ Dr. paed.; Daiva Ramanauskiene ${ }^{2}$ \\ Lithuanian University of Educational Sciences, Lithuania ${ }^{1}$; \\ College of Panevezys, Lithuania ${ }^{2}$ \\ asta.rauduvaite@ leu.lt ${ }^{1}$; daiva.ramanauskieneppt@gmail.com ${ }^{2}$
}

\begin{abstract}
The established integration of children with health problems and special educational needs (SEN) into educational institutions of general purpose, a broader spread of ideas of inclusive education have resulted in a need for a new evaluation of accessibility and provision of special pedagogical support to early age and pre-primary children. The aim is to evaluate the attitude of parents and teachers to accessibility and need of special educational support in early childhood education institutions of general purpose. The empirical research is based on the case study, where the accessibility of special pedagogical support to SEN children in early childhood education institutions of general purpose as well as the attitude of parents and teachers towards the need of such support are analysed. While conducting the research, the survey of the teachers allowed to evaluate the situation of children's special education in educational institutions; the qualitative research revealed the attitude of the teachers and the parents to the analysed problem. It was established that the needs of SEN children are only partially satisfied in early childhood education institutions. It appeared that a part of children, who were assigned a complex support, in most cases received only services of a speech therapist in educational institutions of general purpose. Though parents are recommended to choose an institution with a full team of specialists, they tend to choose the one closer to their home, easier to reach or more attractive. The problem question is raised about who is responsible for partial satisfaction of special educational needs of children.
\end{abstract}

Keywords: special educational needs, special pedagogical support, educational support specialists, school education.

\section{Introduction}

Early childhood and pre-primary age is a significant and specific life-time period for children characterised by a unique social, cognitive and emotional expression of a child. O. Monkeviciene (Monkeviciene et al., 2008) mark this developmental period as valuable in itself and it cannot be regarded only as an intermediate period preparing for life. The recognition and evaluation of peculiarity of children 's development and their educational needs, individualisation and differentiation of teaching, inclusive education which responds to the expectations of learners with special educational needs, parents of such children and teachers constitute the most relevant problems of scientific research on special education at present.

The majority of scholars have been trying to find the answers to the imposed epochal questions: how to provide the most favourable educational conditions for children, who cannot achieve educational standards due to their developmental peculiarities, disabilities or disorders. Following the child's developmental peculiarities, J.D. Coie, K.A. Dodge (1983), C.R. Greenwood, J.C. Delquadri, J.J. Carta (1997) determine theoretical methodological aspects of recognition, evaluation of special education needs of children and satisfaction of them. Over the last ten years scholars have paid enormous attention to recognition of different skills of children and to the search of new educational opportunities. G. Hornby (1999), A. Kirby, R. Davies, A. Bryant (2005), R.P. Goin-Kochel (Goin-Kochel et al., 2007), L. Haiduc (2009) and others have emphasised the importance of inclusive education and conducted broader research on education differentiation considering diverse educational needs and skills of children. Daily efforts of teachers contribute to changes in educational environments that eliminate obstacles for education of children with different educational needs (Watson, 2001; Wolery, Garfinkle, 2002; Kugelmass, Galkienè, 2003; Farell, 2003; Dingle et al., 2004; Kirby, Davies, Bryant, 2005). Inclusive education changes the school community into a collaborating team, whose members solve all the emerging problems in a flexible way extending beyond differentiation of education for a specific school learner. L. Florian (2017), L. Florian, K. Black-Hawkins, M. Rouse (2017) emphasise that the values that school culture is based on and relations of its members predetermine a high degree of inclusion and children's learning achievements. J.W. Kugelmass, M. Ainscow (2004) focus on creation of environments that are favourable for education. The authors have emphasised the importance of integration and inclusive education, flexibility of school system seeking to consider the variety of needs 
of school learners and their parents. Though the methods of special pedagogical support and their application in the practice of education have been intensively researched, the systemic scientific research studies have been scarce particularly regarding special pedagogical support in schools working according to early childhood and pre-primary education curricular.

Early age SEN children (from 3 to 6-7 years) are educated in general or special groups of early childhood education institutions, specialised early childhood education or other institutions of special education. Specialised groups admit SEN children (up to 7 years) with severe and profound special educational needs. On the request of parents, such children can be educated in general purpose or specialised educational institutions. In a general early education institution, a child is educated together with children without any developmental disorders and is entitled to necessary support of specialists. However, most frequently only one specialist is available in nurseries-kindergartens, where early childhood and pre-primary (hereinafter - ECPP) teachers without special preparation face difficulties daily. The main problem is the lack of special pedagogical support specialists in early childhood education schools and insufficient adaptation of educational environments to SEN children.

The research conducted by O. Monkeviciene (Monkeviciene et al., 2008) proved that half of early childhood education institutions apply integrated education of SEN children and one tenth educate such children in specialised groups.

At present the need for significant changes in the system of education has been emerging. The person's life is going on in the space, which is predetermined by certain conditions. Under conditions of inclusive education high quality pedagogical interaction and respect-based environment both in the family and at school become of utmost importance. Inclusive education requires preparation of community members in educational institutions including adaptation of environments, choice of educational aids and, what is most important, team work of participants in the process of education. However, only possibility for education of SEN children in an educational institution of general purpose is not enough. According to every child's capabilities, it is necessary to engage all the learners into educational activities, which have to be adapted and meaningful to each of them. A condition for successful education of SEN children is appropriate preparation of teachers as well as accessible specialist support, when it is necessary.

The aim of the study is to evaluate the attitude of the parents and teachers towards accessibility and need of special pedagogical support in early education institutions of general purpose.

\section{Methodology}

The conducted research was based on the humanist personality education theory and the empowerment theory. The humanist theory (Rogers, Freiberg, 1994; Maslow, 1971) emphasises the person's freedom, the pursuit of self-actualisation, development of inner abilities considering the principles of the theory that an individual is goal-oriented, able to actively seek it and behaves positively in cases when realisation of internal nature is not impeded. Working with individuals suffering from disorders a deep personal contact between two people is much more important than treatment or diagnostics. The main "tools" of support include empathy and unconditional positive attention to a client. The empowerment theory is grounded on stimulation of internal changes and person's education.

The research was conducted in the period of 2016-2017. It included 29 early childhood education institutions attended by 4449 children. The population of working ECPP teachers equalled 480 specialists. Collecting primary empirical data, the methods of document and statistical data analysis were used. The information on educational themes available on the website of X municipality, reports, strategic development plans was studied and the analysis of the situation of early childhood education was conducted based on the collected data. During the research the information publicly available on the internet websites of early childhood education institutions on the services accessible to a child and his/her family, the numbers of child support specialists and their activities was also used.

The oral interview was used to survey the teachers of nurseries-kindergartens and parents. The sample of the qualitative research was compiled applying the method of snowball, when the units of the sample are selected among the people, who know people that are aware of informative cases worth including into the research. Following this principle, the sample embraces units that are relevant to the research and high-quality data are collected. The criteria-based selection was applied, when the researchers 
themselves decide on what respondents have to be selected and insights are draw only about the chosen group or the analysed phenomenon.

All the respondents in the questionnaire survey were teachers $(\mathrm{N}=35)$, who work in early childhood education institutions. Applying the criteria-based selection, the informants were chosen according to the following criteria: work in early childhood education institution of general purpose; work in a group with integrated SEN children; at least 3 years of experience of working with SEN children. The parents included into the sample $(\mathrm{N}=6)$ had to meet the following criteria: to have an early age child with severe SEN; their child attends an early childhood education institution of general purpose.

The direct interview with every informant lasted about 15-20 min. The participants were introduced to the goal of the interview and the topics to be discussed in advance. The answers to the questions were written down and clarified later with every informant. The data collected during the interview were analysed distinguishing categories and sub-categories and generalised using the content analysis, which is appropriate for processing qualitative research data. The categories and sub-categories make the essence of the content analysis (Kondracki, Wellman, Amundson, 2002).

Conducting the analysis of qualitative research data, it was clarified how special pedagogical support to a SEN child is organised in an early childhood education institution, what difficulties are encountered by SEN children and their parents and what services are required by parents.

The research was done applying several methods: document analysis, semi-structured interview, qualitative research data analysis.

\section{Results and Discussion}

Following the data presented by the municipality of $\mathrm{X}$ city, the number of children attending early childhood education institutions has been decreasing the over the last 10 years (4480 children in 2014, 4460 children in 2015, 4400 children in 2016). Optimising the network of early childhood education institutions, the model of institution merger was chosen, which lead to reducing job places of teaching staff and specialists. The reforms have been initiated because of the demographic situation in the country, emigration, an increase in the number of children in groups and the still continuing educational reform.

In the city 6 nurseries-kindergartens have been providing educational assistance to children with more severe special educational needs, where specialised groups for children with language and communication disorders, visual and hearing impairments and complex disabilities are available. Over a year the Pedagogical Psychological Service (PPS) evaluates over 1000 early age children and about 200 school learners, who encounter various educational difficulties. Evaluation of children's abilities most frequently disclose various cognitive, language, behaviour or other problems, disabilities, disorders or impairments, which can be of temporary (e.g. 1-2 years) or permanent character and then specialist support is recommended. Though all the SEN children attending nurseries-kindergartens of general purpose in the city have access to the speech therapist's assistance, only few get support of a special education teacher, a psychologist, a social educator or kinesiotherapist because there are no such specialists in the majority of institutions. Ambulatory services of special pedagogical and psychological support are under-developed, and children particularly lack complex assistance. Meanwhile the reports of public health specialists show that out of all the early age children, who underwent prophylactic medical examination in 2016, only one third were absolutely healthy (mainly visual impairments, cardiovascular diseases, muscular-skeletal disorders prevail).

Seeking to establish the accessibility of special pedagogical support, the supply of services provided to early age children in the city (reflected on the internet websites of institutions) was more comprehensively analysed. During the research, an attempt was made to identify the distribution of child support specialists in early childhood education institutions. The results revealed that 92 specialists work in early childhood education institutions in the city. The majority of them are speech therapists (57), only 10 special education teachers and only several specialists of other areas are available. In educational institutions of general purpose only 3 special education teachers, 1 social pedagogue, 2 psychologists and 2 kinesiotherapists work next to speech therapists there. Thus, the majority of nurserieskindergartens lack teams of child support specialists. It can be assumed that a considerable part of functions of special pedagogical support in institutions are performed by speech therapists or group 
teachers, who do not have any special preparation. If a team of specialists is not available in an institution, a complex support to SEN children is impossible.

The analysis of the teachers' interviews allowed to distinguish the following categories: Problems of children education; Demand for child support specialists; Improvement of system of special pedagogical support.

The sub-categories, such as organisation of education; child's powers and faced difficulties; communication with participants in the educational process, show that the teachers in the research provide evaluation of their abilities to work in a group with integrated children suffering from severe SEN. The teachers indicate problems encountered organising educational activities, distributing attention and differentiating assignments. They also point out that they lack specialised knowledge and experience in solving problem-based situation: Work with a SEN child is most frequently individual, therefore other children do not receive sufficient attention; It is most difficult to equally allocate attention to everybody during the class, that is why, the main attention is allotted to a child with disorders, a particularly agile child, while the others will stay excluded; Preparation of special tasks is highly time-consuming, sometimes it is not clear what tasks should be selected to such children because they do not understand and do not possess fundamental knowledge. Possessing experience in teaching work, the teachers have no problems identifying the child's powers and his/her faced difficulties, they are also aware of the abilities that children of a certain age have to possess: They are able to retain attention only for a very short period of time; They do not understand tasks, they need a lot of explanation; problems of understanding, lack of attention and will; They are very absent-minded, with stormy emotions and unpredictable behaviour; If a hyperactive child is in a group, she/he as if shakes other children and then they all become uncontrollable. The teachers encounter problems understanding the speech of children with language and communication disorders, when they speak little or do not speak at all: during activities behavioural problems of such children emerge, you cannot understand them; undeveloped language creates obstacles; when they cannot express themselves, they start shouting. The respondents stated that it is not easy to communicate with parents of children with developmental disorders, when they expect a special attention to their child from the teacher, though there are 20 other children in the group, who need just as much attention: Mothers imagine that the teacher is going to follow such a child all day long and to satisfy all his or her needs but this is impossible; Parents themselves are strained under such a situation, therefore communication with them is not always successful; <...> insufficient knowledge of how to behave when problems with children and parents emerge. Generalisation of the analysed texts highlighted the problem areas faced working with SEN children: difficulties in organising activities; difficulties of working with SEN children; difficulties in communication with children and cooperation with parents, problems of group management.

The category Demand for child support specialists in the texts was unfolded into the following subcategories: activities of specialists in activities, specialist support to SEN children and teachers.

The research shows that ECPP teachers envisage the meaning of child support specialists in an early childhood education institution and understand the goals of their activities. The respondents working in different institutions expressed similar opinions - long-term specialist support provided in an institution is undoubtedly important to SEN children just as collaboration with teachers and children's parents. The teachers state that: Specialists are prepared to work with children suffering from disorders; Specialists can work individually and allocate more time to a child; More intensive collaboration with the group teacher and parents is necessary; The children's parents need advice and recommendations; Specialists can help teachers adapt programmes and choose methods; A specialist has to help chose ways and content of activities; A specialist professionally discusses and provides well-reasoned recommendations. Some participants highlighted the need for work of child support specialists together with the teacher in the group and pointed out that it is useful to hear recommendations from a specialist. Generalising, it can be stated that ECPP teachers envisage limitations of their work with SEN children, are able to indicate arising challenges, to identify when the specialist's help is needed. There were no participants in the research who doubted the necessity of child support specialists in an early childhood education institution.

The participants in the research were asked to express their opinion about the need for child support specialists in general early childhood education institutions. The category Improvement of system of 
special pedagogical support is disclosed through the sub-categories: demand for child support specialists, possibilities for developing services of support to a child.

The research data allow to state that early education teachers with practical work experience are confident about the need of a specialist team (a special education teacher, a psychologist, a speech therapist, an assistant teacher and a kinesiotherapist) in every educational institution. Psychologists, special education teachers and assistant teachers are at particular request in general nurserieskindergartens. The necessity of specialists in educational institutions is obvious but the participants expressed their concerns about finances: The institution does not possess enough finances to establish new positions for specialists; Employing new specialists, everybody will have to save finances. To improve the functioning of educational assistance, it is recommended to increase responsibility of the community of an institution for performance results; to invite a team of specialists into an institution, who could provide SEN children with short-term consultative assistance. It is acknowledged that all the community members in an institution have to cooperate. The early education teachers request more professional development events, trainings and emphasise the importance to enhance collaboration with SEN children's parents engaging them into the process of education planning and assessment.

During the interview the parents were requested to answer the questions on the basis of personal experience and to express own attitude towards the analysed problem. The parents were asked about difficulties encountered in children's education, motives for choosing a kindergarten, accessibility of special pedagogical support and expectations regarding improvement of special pedagogical support.

After the analysis of the content of the parents' statements about the most frequently faced challenges in SEN children education, the following categories were distinguished: Communication, Emotions and Behaviour, Education (Table 1).

Table 1

\section{The difficulties encountered by parents in education of their children with special educational needs}

\begin{tabular}{|c|l|c|c|}
\hline Category & \multicolumn{1}{|c|}{ Communication } & \multicolumn{1}{c|}{$\begin{array}{c}\text { Emotions and } \\
\text { Behaviour }\end{array}$} & Education \\
\hline \multirow{5}{*}{ Subcategory } & $\begin{array}{l}\text { 1. Communication } \\
\text { difficulties }\end{array}$ & $\begin{array}{l}\text { 1. Management and } \\
\text { control of emotions }\end{array}$ & $\begin{array}{c}\text { 1. Child's powers and } \\
\text { encountered difficulties }\end{array}$ \\
\cline { 2 - 4 } & $\begin{array}{l}\text { 2. Difficulties in language } \\
\text { understanding }\end{array}$ & $\begin{array}{c}\text { 2. Conflicting behaviour } \\
\text { and disobedience }\end{array}$ & $\begin{array}{l}\text { 2. Problems of educational } \\
\text { motivation }\end{array}$ \\
\hline
\end{tabular}

The analysis of parents' texts showed that communication difficulties and difficulties in language understanding are frequently encountered when children are diagnosed with language development disorders: For example, we have problems in making us understood; 〈...〉, others do not understand him at all; He does not allow everybody in, sometimes he chooses whom to talk to and whom not to; I understand that sometimes it is not clear for the people around her what she wants, sometimes it is necessary to ask several times before the girl says or shows something 〈...〉.

The statements within the category Emotions and behaviour emphasise management and control of emotions and conflicting behaviour and disobedience. The parents complain that they are not always able to understand their children's mood and to stop children's mischief: The mood change is very common; When something makes him angry, it is very difficult for him then, but if he is in a good mood, it is peaceful at home as well; I am not always successful in managing my child's behaviour and this makes me desperate; sometimes the child is obedient and then everything is all right. Due to language disorders, undeveloped language, emotional and behavioural disorders children are diagnosed with severe SEN, therefore it is quite clear why namely those difficulties are first mentioned in the parents' statements. It should be mentioned that problems of children's management, just like formation of necessary self-help skills, are some of the most relevant themes. Indicating educational challenges, the parents singled out children's powers and faced difficulties as well as lack of educational motivation. The identification of their child's powers was one of the most complicated tasks for the parents in the research. Parents are still under influence of a stereotypical attitude - speaking about education of SEN children the focus is laid on their weaknesses rather than strengths. Specialists and teachers of 
educational institutions have to more frequently consult parents explaining what a child has learnt or can already perform. The most frequent early education problems among SEN children include: disbalanced child's communication with environment, disability to concentrate and retain attention, to master educational material, to complete tasks on time. They also lack motivation for learning and participation in joint activities with other children.

The parents in the research were asked about the motives of choosing early childhood education institution. Processing of the statements highlighted three categories: Location of an institution, Educational environment, Accessibility of support. The category Location is determined by two subcategories - Close distance from home and Convenient location. The following statements prove the importance of distance of an institution to their home: The kindergarten is close to home and almost in the yard, it suits us; We live nearby, it is convenient; There is a good access, not far from the main street; The kindergarten is not far from my working place, convenient access. Staff and Safe environment that meet the parents' expectations are not less important motives choosing an educational institution. The above-mentioned categories are grouped on the basis of the following texts from the interview: I saw a kindergarten before choosing it, I liked the teachers; 〈...〉 a child gets help here 〈...〉, he is understood there; I leave a child calmly there, I rely on the teacher; I think that my girl is very safe, the teachers nicely communicate with her and understand her; Our child faces more problems than others, he needs a particularly quiet environment. The parents emphasise that their children receive support of specialists (most frequently speech therapists) in the chosen educational institution: Very good teachers are working in the kindergarten as well as speech therapists with huge experience; The speech therapist is most frequently working with a child, but sometimes there comes a coach, my child plays basketball; I receive help. $\langle\ldots>$ Everything suits us, the speech therapist knows her job very well. Other people's feedback on services provided in the nursery-kindergarten is equally important. The parents note that children have an opportunity to stay in an on-duty group, to develop their artistic skills attending artistic education classes and to attend basketball, robotics, dance classes (Table 2).

Table 2

Motives for choosing an early childhood education institution

\begin{tabular}{|c|l|l|l|}
\hline Category & \multicolumn{1}{|c|}{ Location } & Educational environment & Accessibility to support \\
\hline \multirow{2}{*}{ Sub-category } & 1. Close distance from home & 1. Staff & 1. Specialists \\
\cline { 2 - 4 } & 2. Convenient location & 2. Safety & 2. Services \\
\hline
\end{tabular}

The area of accessibility of special pedagogical support and its provision is revealed through the categories Need of special pedagogical support to a child and Involvement of parents in the process of special pedagogical support to a child (Table 3 ).

The subcategories evaluation of special pedagogical support to a child and need for support to SEN children revealed the parents' attitude towards significance of special pedagogical support to a child: More specialists are needed in a kindergarten, who could help to educate a child, who could also provide more services - a psychologist, a masseur; The PPS suggested changing a kindergarten, attending a specialised group but we rejected the recommendation because we were afraid that a child will be among weaker children; I am sure that my child will get better education in a general kindergarten, though more support in such cases could be available here. The parents see and understand that the child's needs are not always satisfied in a kindergarten due to an obvious shortage of specialists: Professional support is insufficient, particularly that of a psychologist, a special education teacher, a social pedagogue and a movement specialist; Children should be provided with more support from specialists; it would be best if professionals could work with children every day.

The texts of such subcategories as parents' information, teaching and consulting and collaboration between parents and teachers show that parents are eager to cooperate with teachers and specialists, but they are not sure if they are able and know what to do in specific situations. In more complicated cases parents feel helpless and want to be consulted: Most frequently I am asked to wait behind the door while the specialist is working with my child; Parents have to be provided with more information, specialists also have to help them because we do not know everything <...>; Specialists could consult parents via Skype; It would be necessary to teach parents how to deal with a difficult child at home, more lectures 
and trainings are needed; A specialist is able to better cope with my child than me, let him or her work because I can fail to understand something $<. . .>$ (Table 3 ).

Table 3

Accessibility of special pedagogical support and its provision

\begin{tabular}{|c|l|l|}
\hline Category & \multicolumn{1}{|c|}{$\begin{array}{c}\text { Need of special pedagogical } \\
\text { support to a child }\end{array}$} & $\begin{array}{c}\text { Involvement of parents in the process of } \\
\text { special pedagogical support to a child }\end{array}$ \\
\hline \multirow{3}{*}{ Sub-category } & $\begin{array}{l}\text { 1. Evaluation of special pedagogical } \\
\text { support to a child }\end{array}$ & $\begin{array}{l}\text { 1. Parents' information, teaching and } \\
\text { consulting }\end{array}$ \\
\cline { 2 - 3 } & 2. Need for support to SEN children & 2. Collaboration between parents and teachers \\
\hline
\end{tabular}

The analysis of the research texts shows that the parents evaluate the work of specialists positively and are happy if their children get support from a speech therapist. They also understand that such support is not sufficient to the majority of SEN children. It can be concluded that special pedagogical support in general early education institutions only partially satisfies the children's needs. The parents expressed a wish to have a bigger variety of educational support specialists in an institution, to receive assistance more frequently, which is not confined only to the speech therapist's work. The parents would eagerly involve into the process of support, would cooperate with specialists if they were properly trained and received constant consultative support. It should be assumed that specialists do not sufficiently trust parents and at present do not consider parents to be equal partners, therefore assume the larger responsibility in the process of activity planning themselves. The parents acknowledge that the lack of specialists in an educational institution of general purpose is a huge problem and understand that an educational institution is not capable of providing all the services of educational support to children with serious SEN but hope that a favourable educational institution, education together with peers and responsibly working teachers are able to compensate insufficiency of targeted pedagogical support.

\section{Conclusions}

Special educational needs of children are only partially addressed in early childhood education institutions because long-term support is provided only by speech therapists. Specialist teams work in two general early childhood education institutions and in six ones with specialised groups in the city X. Despite recommendations from the Pedagogical Psychological Service, some parents tend to choose general early education institutions for their children with more severe SEN because they are closer to their living place or have good recommendations from other parents or their other children have already attended this institution. If special pedagogical support specialists are not available in institutions, a number of children do not receive any targeted long-term support before the start of formal learning.

Teams of special pedagogical support specialists are not available in general early childhood education institutions, therefore communication of specialists assuring quality of SEN children education is limited. The majority of functions assigned to special child support specialists are performed by speech therapists and teachers without special preparation in early childhood education institutions. ECPP teachers lack deeper knowledge necessary for work with SEN children; therefore, they encounter considerable challenges in the process of education. On the other hand, speech therapists are not able to embrace all the areas of special pedagogical support due to big workload and specifics of their professional activity.

The parents of SEN children, who choose general educational institutions, express positive attitudes towards the support provided by specialists (speech therapists) working in them, they are interested in educational perspectives of children with disorders and are open for communication with teachers. The thoughts expressed by parents in the research about the motives of choosing an early childhood education institution, the necessity of special pedagogical support and its provision, expectations regarding development of support in an institution reflect to a positive attitude and an inclination to become active members of a team providing support to a child.

The accessibility of special pedagogical support in early childhood education institutions could be assured by a sufficient number of specialists (speech therapists, special education teachers, social pedagogues, assistant teachers, kinesiotherapists) in early childhood education. Professional long-term 
support would be accessible to SEN children, if, having reviewed their internal resources and implemented structural changes or having grounded the necessity for special pedagogical support, educational institutions established job positions for necessary specialists. Mobile teams of specialists could, at least, partially compensate unavailable services, providing special pedagogical support to children and consulting their parents and teachers. It is important to strengthen collaboration between the community of an institution and parents of SEN children assuming responsibility for the process of SEN children education and its outcomes.

\section{Bibliography}

1. Coie J.D., Dodge K.A. (1983). Continuities and Changes in Children's Social Status: A Five-Year Longitudinal Study. Merrill - Palmer Quarterly, 29(3), 261-282.

2. Dingle M., Falvey M., Givner Ch.C., Haager D. (2004). Essential Special and General Education Teacher Competencies for Preparing Teachers for Inclusive Settings. Issues in Teacher Education, 13(1), 35-50.

3. Farell M. (2003). Understanding Special Educational Needs: A Guide for Student Teachers. USA: Routletge Falmer.

4. Florian L. (2017). The Heart of Inclusive Education is Collaboration. Pedagogy, 126(2), 248-253.

5. Florian L., Black-Hawkins K., Rouse M. (2017). Achievement and Inclusion in Schools. ( ${ }^{\text {nd }}$ ed.). London: Routledge.

6. Goin-Kochel R.P., Myers B.J., Hendricks D.R., Carr S.E., Wiley S.B. (2007). Early Responsiveness to Intensive Behavioural Intervention Predicts Outcomes Among Preschool Children with Autism. International Journal of Disability, Development and Education, 54(2), 151-175.

7. Greenwood C.R., Delquadri J.C., Carta J.J. (1997). Together We Can: Class-Wide Peer Tutoring to Improve Basic Academic Skills. Longmont, CO: Sopris West.

8. Haiduc L. (2009). School Integration of Children with Autism. Acta Didactica Napocensia, 2(1), 27-34. Retrieved from http://dppd.ubbcluj.ro/adn/article_2_s1_5.pdf

9. Hornby G. (1999). Inclusion or Delusion: Can One Size Fit All? Support for Learning, 14(4), 152-157. Retrieved from https://www.academia.edu/27560595/Inclusion_or_Delusion_Can_one_size_fit_all

10. Kirby A., Davies R., Bryant A. (2005). Do Teachers Know More About Specific Learning Difficulties than General Practitioners? British Journal of Special Education, 32(3), 122-126.

11. Kondracki N.L., Wellman N.S., Amundson D.R. (2002). Content Analysis: Review of Methods and their Applications in Nutrition Education. Journal of Nutrition Education and Behavior, 34(4), 224-230.

12. Kugelmass J.W., Ainscow M. (2004). Leadership for Inclusion: A Comparison of International Practices. Journal of Research in Special Educational Needs, 4(3), 133-141.

13. Kugelmass J.W., Galkiene A. (2003). Education in Post-Soviet Lithuania and the Inclusion of Children with Special Education Needs. In J.W. Kugelmass, J.R. Dennis (Eds.). Advocating for Children and Families in an Emerging Democracy: The Post-Soviet Experience in Lithuania, Chapter 4. USA: Information Age Publishing, 63-92.

14. Maslow A.H. (1971). The Farther Reaches of Human Nature. New York: Arkana/Penguin Books.

15. Monkeviciene O., Glebuviene V.S., Joniliene M., Montvilaite S., Stankeviciene K., Mauragiene V., Tarasoniene A.L. (2008). Ikimokyklinio Ugdymo Ivairove: Esama Situacija ir Visuomenes Lukesciai (The Variety of Early Childhood Education: Current Situation and Society's Expectation). Vilnius: Vilniaus Pedagoginis Universitetas. Retrieved from https://www.smm.lt/uploads/documents/kiti/VPU-atask-paslaug-ivairove.pdf (in Lithuanian)

16. Rogers C.R., Freiberg H.J. (1994). Freedom to Learn. (3 ${ }^{\text {rd }}$ ed.). CA: Pearson.

17. Watson J. (2001) Social Constructivism in the Classroom. Support for Learning, 16(3), 140-147.

18. Wolery M., Garfinkle A.N. (2002) Measures in Intervention Research with Young Children who have Autism. Journal of Autism and Developmental Disorders, 32(5), 463-478. 